\title{
The history, status and trends of the Endangered Seychelles Magpie-robin Copsychus sechellarum
}

\author{
APRIL J. BURT, JULIE GANE, IAIN OLIVIER, LICIA CALABRESE, \\ ARJAN DE GROENE, TANYA LIEBRICK, DANE MARX and NIRMAL SHAH
}

\section{Summary}

The once 'Critically Endangered' Seychelles Magpie-robin was down to just 12 individuals in 1960 on one island of the granitic Seychelles. In 2015, due to intensive long-term management the population stands at around $28 \mathrm{o}$ birds on five islands, marking a significant success for this species. Translocations to the islands of Cousin and Cousine have led to population saturation and stability, a translocation to Denis Island has resulted in a continuing population increase and the founder population on Frégate Island is likewise increasing. The latest translocation to Aride Island in 2002 resulted in population increase then stability but is now showing a steep decline throughout 2014 into 2015. Reasons for this decline are yet unknown though disease, lack of recruitment, the impacts of social conflict and the possibility of genetic issues are discussed. This report summarises the history of management for this species, compiling all available published and unpublished information, to provide a comprehensive account of the Seychelles Magpie-robin recovery.

\section{Introduction}

The Seychelles Magpie-robin Copsychus sechellarum is one of six Seychelles endemic birds that have suffered population declines to the point at which they are classed as 'Vulnerable', 'Endangered' or 'Critically Endangered' on the IUCN Red List. Such declines are especially prevalent in small island populations and can be attributed to the effects of exotic animal species introductions and habitat destruction (Johnson and Stattersfield 1990, Szabo et al. 2012).

Critical habitat requirements for the Magpie-robin are specifically bare earth and leaf litter occurring under mature shady woodland (Watson et al. 1992). Magpie-robins form small social groups comprised of a dominant pair and a number of subordinates, varying from one to eight and living to a maximum of 15 years (Gane and Burt 2016). Each social group defends a common territory that they rely on for nesting sites, foraging areas and water (López-Sepulcre et al. 2008, McCulloch 1996). Each territory varies in quality and size causing individuals and social groups to compete for and extend existing territories into higher quality habitat areas (López-Sepulcre et al. 2010).

Evidence suggests that the Seychelles Magpie-robin was once common throughout the granitic Seychelles (Newton 1867, Vesey-Fitzgerald 1940) although confirmed records are restricted to Mahé, Southeast Island, St Anne, Praslin, Aride, La Digue, Marianne and Frégate (Newton 1867, Pike 1872, Hartlaub 1877, Oustalet 1878, Lionnet 1980). Since these initial observations, there was a drastic population decline corresponding to habitat destruction through clearance for agricultural land and the introduction of alien predators such as rats and cats. On Mahé, 
Praslin and Marianne it disappeared in 1883,1878 and 1948 respectively (Crook 1960, Blackburn 1883). Over-collection of specimens may have contributed to decline on some islands (Oustalet 1878). It was introduced to Alphonse at some time prior to 1892 (Ridgway 1895) and was still present in 1940 (Vesey-Fitzgerald 1940) but extinct by 1965 (Gaymer et al. 1969). Aride was one of the few islands still hosting a Magpie-robin population around 1870 (Hartlaub 1877, Oustalet 1878) together with Frégate (Pike 1872, Hartlaub 1877). It survived on Aride until the 1930s (P. Medor verbally in Skerrett et al. 2001).

The Magpie-robin was first reported on Frégate in 1871 (Pike 1872). By 1960, Frégate held the last remaining population, consisting of only 12 individuals (Dawson 1965). Between 1965 and the start of the recovery programme in 1990, the population size fluctuated with varying efforts to eradicate cats and rats as well as management of forest areas. A maximum of $38-41$ individuals was recorded in 1977-1978 (Watson 1978) and by 1988-1990 the population had declined to 17-21 birds.

In 1990, in response to their 'Critically Endangered' status, a recovery programme was initiated by the International Council for Bird Preservation (now BirdLife International) and funded by the Royal Society for the Protection of Birds (RSPB). This effort was managed by Birdlife Seychelles from 1993 (Birdlife Seychelles became Nature Seychelles in 1998). The programme included predator eradication, supplementary feeding, provision of nest boxes, and habitat restoration; a ban on the use of organophosphate and carbamide pesticides was also implemented. This intensive programme resulted in a rapid increase in numbers (Norris and McCulloch 2003) and made possible new translocations of individuals to the islands of Cousin in 1994, Cousin and Cousine in 1995, Aride in 2002 and most recently to Denis in 2008 (López-Sepulcre et al. 2008, Gerlach and Le Maitre 2009). The Magpie-robin recovery effort is ongoing and the management of this species is reliant upon SMART (Seychelles Magpie-robin Recovery Team), which regroups the different organisations that manage islands with Magpie-robin populations. Contributing members are composed of island managers/owners and conservation management staff. The Magpie-robin recovery plan aimed to have island owners take responsibility of their Magpie-robin populations by 2000 and this has been successful with overall SMART coordination by Nature Seychelles in the form of annual meetings, data sharing and newsletters. The Magpie-robin was downlisted from 'Critically Endangered' to 'Endangered' in 2005.

This report aims to compile all available information, describe the current status of the Seychelles Magpie-robin on all five islands, show trends, outline management strategies and provide recommendations for the continued safeguarding of this species. It is intended to be used as a reference to provide clarification and outcomes of past management in aid of all future management decisions.

\section{Methods}

\section{Compiling existing information}

All available published information, unpublished reports, SMART data and reports on distribution, movements and population of Seychelles Magpie-robin were consulted.

\section{Field data collection and management}

From the start of the recovery programme, an endeavour to ring each bird has been made; one leg to hold an individually numbered metal ring (SAfring) as well as a colour ring denoting the individual's natal island $($ Cousin $=$ red, Cousine $=$ sky blue, Aride $=$ yellow, Frégate $=$ new green and Denis $=$ orange), the other leg has a two ring colour combination unique to the individual on that island. This has ensured ease of monitoring on each island and enables highly accurate population counts.

The populations have been monitored as closely as possible since translocation, providing information on the number of territories, territory occupancy, behaviour, breeding success, lifespan, annual survival and social status. A database is held for each island, detailing individual hatching dates, sex, parentage and approximate date of death. A standard monitoring protocol was 
established and further details can be found in Bristol et al. (2005). Birds were considered dead or missing from the island if they were not seen for three consecutive months, change of territories were recorded after a bird had been recorded in a different territory three consecutive times. Breeding attempts were followed closely and chicks were ringed prior to or shortly after leaving the nest. Blood samples have been sent to the Royal Netherlands Academy of Arts and Sciences to determine the sex of each bird.

\section{Island descriptions}

\section{Frégate}

Frégate is the easternmost of the granitic inner islands $\left(4.5833^{\circ} \mathrm{S}, 55.93333^{\circ} \mathrm{E}\right)$, lying $55 \mathrm{~km}$ east of Mahé and rising to a height of $125 \mathrm{~m}$ above sea level (Figure 1). Frégate has a total area of 219 ha encompassing two coastal plateau areas with a combined area of approximately 30 ha. Frégate currently operates as a privately owned luxury eco-friendly resort. Agricultural activities in the I9oos led to virtually all of the island's natural forest being cleared; species such as coconut, cinnamon, cashew, coco plum, and mango were then planted. Despite this, the island retained many important plant and animal species endemic to Frégate Island and the Seychelles. Today significant areas have undergone habitat restoration, and work is ongoing. Large cleared patches around the hotel developments were replanted primarily with native tree species following construction, and in later years many other specific, targeted areas have undergone planting of native tree species and removal of invasives.

\section{Aride}

This is the northernmost granitic island of the Seychelles Archipelago $\left(4.2000^{\circ} \mathrm{S} 55.6667^{\circ} \mathrm{E}\right)$. The island is situated $10 \mathrm{~km}$ away from Praslin and $50 \mathrm{~km}$ from the main island of Mahé (Figure $\mathrm{I}$ ).

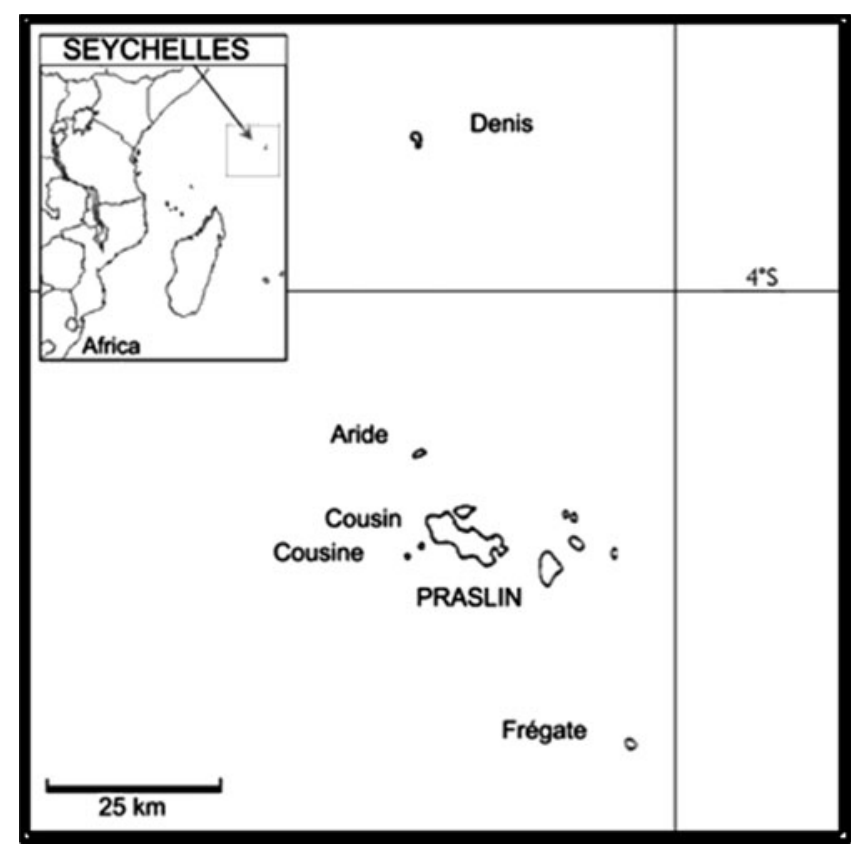

Figure 1. Map of the five Seychelles Islands which currently hold Magpie-robin populations. 
Aride has an area of 74 ha of which 5 ha are flat and 69 ha are mountainous with a maximum elevation of $134 \mathrm{~m}$. Aride was once a coconut plantation and the hill vegetation was continuously cleared to allow the Sooty Tern Onychoprion fuscatus to breed for egg harvesting. Aride Island was purchased in 1973 by the Society for the Promotion of Nature Reserves (SPNR), now the Royal Society of Wildlife Trusts (RSWT) with funds provided by Christopher Cadbury. The coconut plantation was removed and native vegetation gradually restored. In 2004 RSWT took the decision to pass responsibility for Aride to a local conservation organization, the Island Conservation Society (ICS) and after ICS satisfied various conservation targets, ownership was passed to the related UK- registered charity Island Conservation Society UK in 2008. At present the whole island is dominated by native forest. The island became a Special Reserve in 1975 under Seychelles law. The only residents of the island are on average six reserve staff members and a few volunteers. The island is open to the public each weekday from 10:00 to 15:00 for guided tours carried out by the staff members.

\section{Cousin}

Cousin is a low lying Island of 27 ha $\left(4.3314^{\circ} \mathrm{S}, 55.6631^{\circ} \mathrm{E}\right), 2 \mathrm{~km}$ off the coast of Praslin and consists of dense forest on the plateau and a hill $69 \mathrm{~m}$ above sea level (Figure 1 ). It was once a coconut plantation but was restored to its current state to ensure the survival of the endemic Seychelles Warbler Acrocephalus sechellensis. The island was bought in 1968 with funds provided by Christopher Cadbury and the Royal Society for Nature Conservation, and an international funding appeal. Initially managed by the International Council for Bird Preservation, it is now owned by BirdLife International and managed by a local NGO, Nature Seychelles, the BirdLife country partner. The island has been protected since 1969 and was awarded the status of IUCN class 1a Special Reserve in 1975. The only residents of the island are the reserve wardens, a scientific officer and visiting researchers and volunteers. The island is open to the public for two hours in the morning of each weekday for strict guided tours.

\section{Cousine}

Cousine Island is a 26 ha granitic island $\left(4.3500^{\circ} \mathrm{S}, 55.6333^{\circ} \mathrm{E}\right)$. It is just over $\mathrm{I} \mathrm{km}$ long, $400 \mathrm{~m}$ wide and $70 \mathrm{~m}$ at its highest point (Figure 1 ). The island is privately owned and is run primarily for conservation. Four villas are present, which provide a necessary source of income to support conservation activities. There are a maximum of 18 resident staff members on the island. The island was previously degraded by human settlement and agricultural activities in the 1960s. An intensive restoration project was started after the present owner purchased the island in 1992. A total of 25 invasive alien plants and all alien vertebrates were eradicated shortly after the projects initiation (Samways et al. 2010).

\section{Denis}

Denis Island is a low-lying sand cay $\left(3.8000^{\circ} \mathrm{S}, 55.6667^{\circ} \mathrm{E}\right)$ approximately $80 \mathrm{~km}$ north of Mahé (Figure 1). It is approximately 140 ha in area (Hill et al. 2002), although there is evidence of rapid erosion in the past (Fryer 1910). The maximum elevation is less than $4 \mathrm{~m}$ above sea level and average surface elevation is around $2.5 \mathrm{~m}$ (Stoddart and Fosberg 1981). Unlike the majority of islands on the Seychelles Bank, Denis has no granite and it is formed entirely of reef-derived sands. Compared to the granitic islands to the south, Denis Island is relatively remote; the nearest island that hosts a resident Magpie-robin population is Aride, approximately $45 \mathrm{~km}$ to the south. In the 19th and 2oth centuries the island underwent complete transformation, first through the cultivation of coconuts, planted from around 1890 (Stoddart and Fosberg 1981), then guano extraction from 1929 to 1941 (Baker 1963), and finally by the extensive replanting of coconuts. In 1996, the current owners acquired the island. Today, Denis is privately owned and managed as 
a resort with 25 villas. The permanent population of the island (80-10o people) is employed in the hotel and tourists travel to Denis by small plane from Mahé.

\section{Translocations}

Prerequisites for translocation included a) a lack of alien predators, b) appropriate habitat type, namely large areas of native forest, c) evidence of good feeding conditions, namely soil invertebrates, d) commitment by island owners to conserve and monitor the population, and fulfil posttranslocation commitments.

\section{Desirable long-term post-translocation commitments}

1. Providing at least two nest boxes per territory. Following the provision of open-fronted nest boxes on islands, nesting success improved and the fledging rate from nest boxes was $44 \%$ compared to $28 \%$ from coconut palm crowns and $38 \%$ from natural nest sites. (Lucking and Lucking 1997).

2. Supplementary feeding and water supply to birds after initial release as necessary.

3. Employment of a conservation officer responsible for the close monitoring of Magpierobins. This role includes compiling monthly reports to be submitted along with data sheets to the SMART coordinator.

4. Daily observations conducted following the Magpie-robin monitoring protocol set out first by Lucking and Lucking (1997), then by Bristol et al. (2005).

5. A strict biosecurity protocol, including continued eradication of invasive alien predators and competitors, such as cats, rats Rattus spp., Barn Owl Tyto alba and Common Myna Acridotheres tristis.

6. Ringing, biometrics and blood sampling of each fledgling to be carried out.

7. Active habitat management to maintain suitable Magpie-robin habitat.

8. Ban on the use of organophosphate and carbamide pesticides.

\section{Aride}

Seven attempts have been made to establish Magpie-robins on Aride: in 1978 (six birds), 1979 (four birds), 1992 (one bird x2), 1994 (one bird), 1995 (six birds) (Watson 1978, Lucking and Ayrton 1995, Parr 1998) and 1999 (one bird) (Millett and Shah 2000). An additional attempt to promote breeding in 2000 was made by transferring a fertilised egg from Cousin to Aride but although the egg successfully hatched the chick did not survive to fledge. These attempts did not establish a breeding population with failures due to high post-release mortality, thought to be a combination of stress, predation by Barn Owls and bacterial infection by Erysipelothrix rhusiopathiae (Lucking and Lucking 1997). On the morning of 23 January 2002, 15 Magpie-robins were transported in carrying cages by helicopter from Frégate to Aride Island. The birds were then placed and held in four flight aviaries (corresponding to release sites), and fed /monitored three times a day until 20 February 2002 when they were released into the wild. The existing non-breeding pair on Aride were caught prior to this translocation and were taken off the island by boat on 23 January 2002 and held in aviaries on Frégate and subsequently released. The reason for their removal was to reduce territory conflicts and to promote dominance by new breeding pairs. The first breeding attempt was initiated three weeks after release and resulted in the successful recruitment of a chick to the Aride population.

\section{Cousin}

Four birds (two males, two females) were released on Cousin on 14 November 1994. All birds survived the translocation and settled in well, but one female died after a large storm and was 
replaced in March 2005 by another female from Frégate (Le Maitre 1995a). In October 1995 another two birds (male and female) were translocated from Frégate. The final translocation was in November 1996 with two birds (male and female) translocated from Frégate (Le Maitre 2006a,b). The first chick was born on Cousin on I May 1995, 5.5 months after the original translocation.

\section{Cousine}

Cousine Island received its first Magpie-robins in October 1995, with an original three birds (two male, one female) from Frégate via helicopter. The female died after just a few weeks and a further three Magpie-robins (two female, one male) were translocated in January 1996 from Frégate. The final translocation of one female took place in November 1996 from Cousin Island via boat. The exact date of first successful breeding attempt is not recorded though it is thought to be in the first quarter of 1996.

\section{Denis}

In June 2008 sixteen Magpie-robins originating from Frégate Island and four from Cousin Island were introduced. The first chick was born on 23 August 2008, just two months after translocation.

\section{Management}

\section{Frégate}

Management of the Magpie-robin population began in the 196os with attempts to remove feral cats Felis catus that were introduced in the 1950s (Crook 1960). Whilst removal efforts continued from 1960 onwards they were not completely eliminated until an eradication programme by ICBP and New Zealand Wildlife Service was carried out in 1981-1982. In 1978 and 1979, translocations to Aride of six and four birds respectively were carried out based on the apparent resilience of the Frégate population at this time (Watson 1978, Watson et al. 1992). Recruitment in relation to adult mortality appeared to be high and up to a dozen non-breeding adults were present in the population to replace the breeding individuals which were translocated (Watson 1978). The translocations were unsuccessful and by 1980 Frégate once again held the only breeding population. After this time, low recruitment due to habitat degradation, was deemed to be the principal factor limiting the recovery of the population (Watson et al. 1992, Komdeur 1996).

BirdLife International began research on Frégate in 1988 for the subsequent recovery programme initiated in 1990. Habitat restoration has been ongoing with the removal of invasive scrub layers as well as larger scale removal of invasive trees and subsequent replanting of native species. Frégate remained rat free until July 1995 when it was colonised by Norway rats Rattus norvegicus. An initial attempt at eradication was abandoned in 1996 after several Magpie-robins died through secondary poisoning (Thorsen et al. 2000, Merton 2001). A large-scale eradication programme was initiated in 2000 and prior to baiting, 39 Magpie-robin were taken into captivity and held in rat-proof enclosures for the duration of bait availability (II weeks) (Merton 2001). Since the eradication of rats in 2000, Frégate has remained rat-free and operates a strict biosecurity protocol enforced by the resident conservation staff. The presence of the Common Myna was considered a threat to the survival of the Magpie-robin on Frégate and as such several unsuccessful eradication attempts were made using a police marksman and nest box trapping (Millett and Shah 2000). A successful eradication effort using cage trapping was initiated in 2010 and a total of 745 birds were destroyed in eight months (Canning 2011). These conservation actions resulted in a rapid population increase, allowing the start of translocations of individuals from Frégate to the other inner-granitic islands. Supplementary feeding on Frégate began with the recovery program but was phased out in 2001-2002 (Bristol et al. 2005). 
There is currently a resident ecologist employed on Frégate responsible for the monitoring of the Magpie-robin and continual implementation of the recovery programme. The population on Frégate is now mostly ringed although in the past, monitoring frequency and ringing efforts have been inconsistent. Nest boxes are provisioned in each territory. The size of the Frégate Magpie-robin population and the overall terrain occupied by Magpie-robin make it harder to monitor the population closely. A population census and territory mapping exercise is carried out bi-annually.

\section{Aride}

The entire Magpie-robin population on Aride has been individually colour ringed and metal ringed since the last translocation to present. Mortality during the first five months of establishment was high, c. $50 \%$, however seven breeding attempts were recorded during the first nine months from the last translocation producing two pulli (Shah and Parr 2002). Supplementary feeding for the Aride population is still ongoing with the aim of supporting a very slow growing population until it reaches a minimum of 30 birds. Nest boxes are installed in each territory to aid and facilitate successful nest building. Habitat management is carried out to improve quality of foraging habitat, especially on the hill.

\section{Cousin}

The entire Magpie-robin population on Cousin has been individually colour ringed and metal ringed since translocation to the present. The population has been monitored weekly for close to 20 years, following the post-translocation commitments. Management of Cousin has remained steady throughout the past 20 years, with consistent effort from a dedicated science officer and reserve wardens. No supplementary feeding has been necessary on Cousin since 1996 due to high levels of ground dwelling invertebrates and insects. Active habitat management is required across the island to remove the invasive scrub layer that can cover key Magpie-robin foraging habitat, particularly during the rainy season. Nest boxes are present in each territory and regularly maintained.

\section{Cousine}

Since the translocation of the first Magpie-robin individuals to Cousine Island, intense monitoring and record keeping has been a priority. This commitment has enabled Cousine Island to fulfil obligations to the SMART programme post-translocation commitments. A minimum of weekly observations has been conducted and all birds to the present have been recorded and ringed. Each individual that ever existed on the island has an individual profile comprising hatching and fledging dates; territory of birth; territory occupancy over its life span; parentage; date of death and where possible reason for death. Supplementary food using Kaytee Exact Softbill bird food was provided on an ad hoc basis until 2007. Water tables were erected in each territory in order to provide a constant source of fresh water for all the Magpie-robins on the island. Each of the nine territories contains one or two nest boxes that were erected in the recommended manner according to the specific requirements of Magpie-robin nesting habits. Habitat maintenance and management is ongoing with the removal of ground-covering invasive shrubs and planting in those territories requiring additional canopy cover to ensure ideal foraging habitats into the future.

\section{Denis}

Following translocation, the Magpie-robin population was monitored weekly and each individual ringed for the first year. No supplementary feeding has been necessary on Denis after the first two years. Since then a population census has been performed annually to monitor any population trends, though close monitoring of the birds and continued ringing has not been consistent since 
translocation. In total, more than 25 nest boxes were installed throughout the island. Habitat rehabilitation and maintenance is in progress (Hill 2001) to ensure an adequate amount of nesting and foraging areas across the island. Additionally, Common Myna eradication restarted in 2010 (Feare et al. 2010) and was successfully completed in 2015 to remove the threat of egg and fledgling predation.

\section{Results}

\section{Current status}

Current population as of September 2015 stands at c.280 individuals across five islands (Figure 2a) and the population overall has an upward trend. Table 1 shows current population numbers for each island; Cousin, Cousine and Aride show exact population numbers due to daily monitoring and easily defined territories. Denis Island conducted a full census in 2015; Magpie-robin

a) Total Magpie-Robin Population

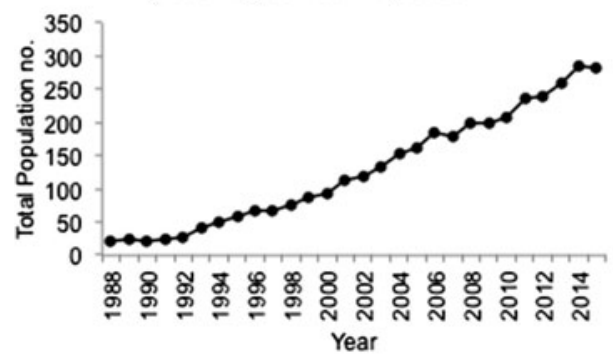

C) Aride Magpie-Robin Population

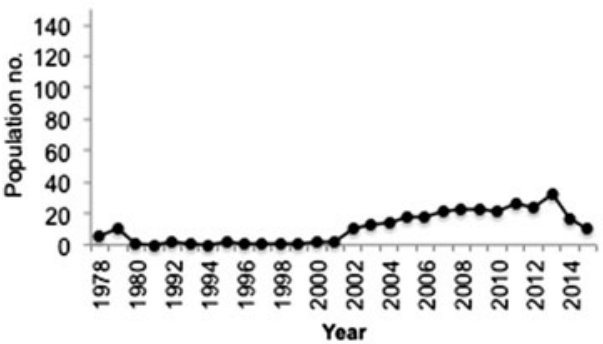

e) Cousine Magpie-Robin Population

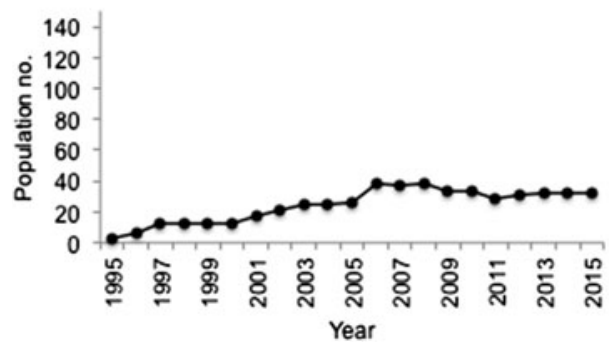

b) Fregate Magpie-Robin Population

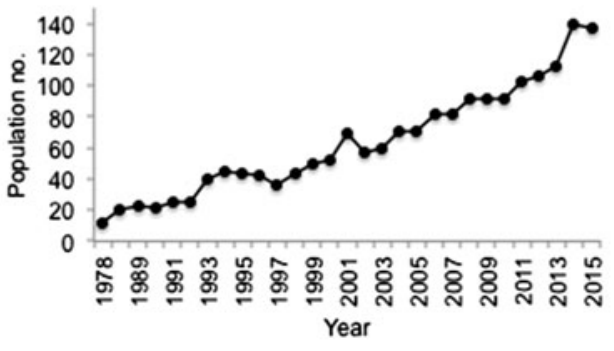

d) Cousin Magpie-Robin Population

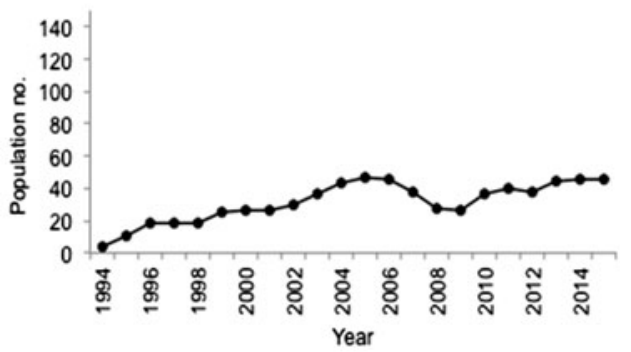

f) Denis Magpie-Robin Population

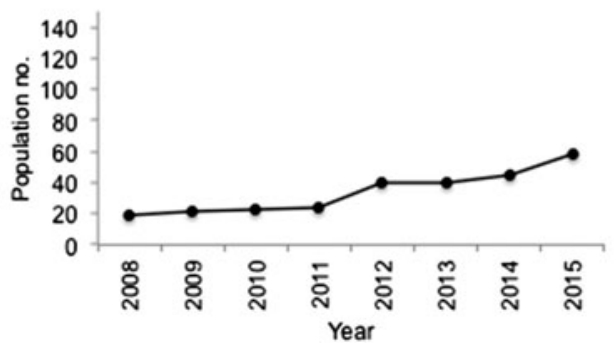

Figure 2. Population expansion of the Seychelles Magpie-robin. Total population 1978-2015 (2a); Frégate Island 1978-2015 (2b); Aride Island since first translocation 1978-2015 (2c); Cousin Island since translocation 1994-2015 (2d); Cousine Island since translocation 1995-2015 (2e); and Denis Island since translocation 2008-2015 (2f). 
Table 1. Seychelles Magpie-robin status summary.

\begin{tabular}{|c|c|c|c|c|c|}
\hline Island & Size (ha) & $\begin{array}{l}\text { Current } \\
\text { Population }\end{array}$ & Current Trend & Translocations & References \\
\hline Frégate & 219 & 137 & Increasing & 2002 ( 2 birds from Aride) & Thompson 2002 \\
\hline Aride & 74 & 10 & Decreasing & $\begin{array}{l}1978 \text { (6 birds from Frégate) } \\
1979 \text { ( } 4 \text { birds from Frégate) } \\
1992 \text { ( } 1 \text { bird from Frégate) } \\
1992 \text { ( } 1 \text { bird from Frégate) } \\
1994 \text { ( } 1 \text { bird from Frégate) } \\
1995 \text { ( } 6 \text { birds from Frégate) } \\
2000 \text { ( } 1 \text { bird from Cousine) } \\
2000 \text { ( } 1 \text { egg from Cousin to } \\
\text { Aride) } \\
2002 \text { (15 birds from Frégate) }\end{array}$ & $\begin{array}{l}\text { Watson et al. 1992, } \\
\text { Lucking \& Ayrton } \\
\text { 1994, Lucking \& } \\
\text { Ayrton 1995, } \\
\text { Thompson } 2002\end{array}$ \\
\hline Cousin & 27 & 46 & $\begin{array}{l}\text { Stable at } \\
\text { carrying } \\
\text { capacity }\end{array}$ & $\begin{array}{l}1994 \text { (4 birds from Frégate) } \\
1995 \text { ( } 1 \text { bird from Frégate) } \\
1995 \text { ( } 2 \text { birds from Frégate) } \\
1996 \text { ( } 2 \text { birds from Frégate) }\end{array}$ & $\begin{array}{l}\text { Le Maitre 1994, 1995a, } \\
\text { 1995b, 1996a, 1996b, } \\
\text { Mee 1996. Parr and } \\
\text { Shah 1999. }\end{array}$ \\
\hline Cousine & 26 & 32 & $\begin{array}{l}\text { Stable at } \\
\text { carrying } \\
\text { capacity }\end{array}$ & $\begin{array}{l}1995 \text { ( } 3 \text { birds from Frégate) } \\
1996 \text { ( } 3 \text { birds from Frégate) } \\
1996 \text { ( } 1 \text { bird from Cousin) }\end{array}$ & Le Maitre 1996a \\
\hline Denis & 131 & 58 & Increasing & $\begin{array}{l}2008 \text { (16 birds from Frégate, } \\
4 \text { birds from Cousin) }\end{array}$ & \\
\hline
\end{tabular}

monitoring frequency is increasing on Denis Island since the appointment of a full-time conservation manager and increased conservation staff since early 2015. The Frégate population stretches over a wider area making frequent population counts challenging; staff conduct bi-annual Magpierobin censuses with monitoring of breeding throughout the year.

\section{Trends}

\section{Frégate:}

Figure $2 \mathrm{~b}$ shows the changes in the Magpie-robin population since its lowest point in 1978. The Frégate Island Magpie-robin population remained fairly stable for the first few years of the recovery programme, with a substantial increase in 1992-1993. The decline in numbers from 1994 to 1997 can be attributed to three translocations to other islands in this period ( 22 individuals in total), but this also coincided with the accidental introduction of Norway rats in 1995 and secondary poisoning of some individuals following an unsuccessful eradication attempt in 1996. The population shows a marked increase following the second successful eradication, which included the captive birth of seven juvenile Magpie-robins while the population was housed in aviaries during the eradication process. The decline seen from 2001 to 2002 is only partially explained by the translocation of 15 birds from Frégate to Aride in 2002. Thereafter the population exhibits a marked and steady growth from 2002 onwards, even with the translocation of 16 birds to Denis island in 2008. The particularly marked population growth from 2013 to 2014 may be a delayed response to the successful eradication of Common Mynas.

Aride:

Figure $2 \mathrm{c}$ shows the evolution of the Magpie-robin population on Aride since the very first translocations (with the most recent 2002 being the only successful one) until September 2015. After a sudden decrease in the number of individuals following the 2002 translocation (a significant loss 
of birds occurred between March and June, with seven individuals either missing or located dead, losses to the translocated stock were anticipated, but were higher than expected), the population soon stabilised at eight birds and the first successful breeding attempts were recorded. The population started to grow slowly but constantly until 2005 when there was another decrease in bird numbers. From 2005 to 2007 the population grew again gradually to 20 individuals. The maximum number of birds recorded was in 2013 with 32 individuals in seven territories. In September 2015 the population stands at 1o birds showing a steep decline since early 2014. An unknown disease/infection resulting in the mortality of several young chicks in the latter half of 2013 and a very low recruitment success rate are thought to be the cause for this decline though further investigation is underway.

Of the seven territories, five are in the plateau and two on the hill. One of the hill territories is frequently abandoned, likely due to the poor habitat conditions, though it is always recolonised by a single bird or a pair. The population has rarely passed 30 birds in seven territories and it is unlikely it will surpass this number until the hill habitat improves. Another possible limitation for colonisation of the hill by the Magpie-robin could be the lack of water sources, as during the south-east monsoon the island becomes very dry, limiting the chance of a permanent population becoming established on the hillside. Breeding success has always been high but recruitment low and observations indicate that some juveniles are chased away from the natal territory as soon as they reach independence from the parents. These juveniles often disappear. The birds on Aride are quite tame due to artificial feeding so it is easy to observe them during the weekly and daily monitoring, even on the hill territory, as whistling normally attracts them.

\section{Cousin}

Figure $2 \mathrm{~d}$ shows the evolution of the Magpie-robin population on Cousin since translocation until September 2015. Maximum number of territories is 11 although this fluctuates between 10 and II from year to year. Maximum number of birds recorded on Cousin peaked at 47 in 2005 and again in 2013 and 2015 with 46 individuals. The population is currently stable at 46 birds in 11 territories and is considered to be a saturated population. Breeding success was high during 2014 and 2015 and average adult annual survival is $81.6 \%$ over the past 19 years (Gane and Burt 2016). A dip in numbers can be seen in 2006 and again in 2008. There seems no obvious reason for the 2006 reduction to 31 birds apart from natural population regulation (caused by territory or dominance disputes which are often deadly). López-Sepulcre et al. (2008) suggest the dip may have been caused by potential cumulative effects of inbreeding based on such a small founder population. This does not seem to be the case, as eight years later the population on Cousin has recovered. The 2008 population dip can be attributed to the translocation of four birds from Cousin to Denis Island. The Cousin birds have become conditioned to appear on whistling due to receiving the reward of an over-turned rock or some leaf litter cleared for them to feed and this has been an extremely useful tool when carrying out weekly territory checks.

\section{Cousine}

Figure ze shows the evolution of the Magpie-robin population on Cousine since translocation until September 2015. After receiving its first seven birds from Frégate Island between October 1995 and November 1996, the Cousine Island Magpie-robin population steadily increased until it reached a maximum of 40 birds in November 2006. Numbers subsequently stabilised between 29 and 37 birds, with an average of 33 individuals over the last 8 years. Average adult annual survival for Cousine is $77.9 \%$ over an 18 year period (Gane and Burt 2016). There have been no major annual dips in the population, but one major monthly dip between September and October 2010 was recorded when the population dropped from 35 individuals to 28 . This was believed to be a result of the population exceeding the island's carrying capacity, creating 
territorial conflicts and migration. There is a maximum of nine territories, with seven territories continually occupied. The original three territories defined between 1996 and 1998 have split at various times creating smaller territories as the population has increased, with the addition of three new territory sites. The first ever recorded twins hatched on Cousine on the $17^{\text {th }}$ December 2001. Subsequently two sets of twins have been recorded, with only one pair surviving until fledging age.

\section{Denis}

Figure $2 \mathrm{f}$ shows the evolution of the Magpie-robin population on Denis Island since translocation until September 2015. After translocation, the population remained stable at around 20-25 birds for three consecutive years. Since 2010 when the Common Myna eradication project began, the Magpie-robin population has increased to a maximum of 58 individuals by September 2015. It is thought that now the Common Myna eradication has been completed on Denis the population will increase further. In addition, an area of approximately 12.5 ha of coconut plantation has been restored to broadleaf forest and continues to become established, which has increased the quantity of suitable habitat. However, this area currently has limited open areas suitable for Magpie-robin feeding, though in time it is hoped this forest rehabilitation effort is likely to increase habitat quality. At present it is assumed that the Common Myna eradication has been the major driver of the increase in Magpie-robin population on Denis Island.

\section{Inter-island movements}

There have been 14 known incidents of inter-island movement (Table 2). This figure can be considered robust when considering the continuous nature of monitoring for this species. Should an unknown bird appear within the population then conservation staff would be able to identify it as a non-natal bird based on its colour rings. Birds that migrate to non-Magpie-robin islands such as Praslin or Curieuse are conspicuous and likely to be reported. It is not known whether a higher number of birds attempt migration and fail. Most inter-island movement has occurred between Cousin and Cousine, the closest of the Magpie-robin islands (Shah and Parr 1999). A migration to Denis Island from Aride - a distance of $45 \mathrm{~km}$ - presents the longest natural colonisation event for the species.

Table 2. All recorded incidents of Magpie-robin inter-island movement.

\begin{tabular}{|c|c|c|c|c|}
\hline Date & From & To & Outcome & Reference \\
\hline 1997 & Cousin & Praslin & Disapear & SMART News 2, 2002 \\
\hline 2000 & Cousine & Cousin & Success & QRep 4 \\
\hline 2000 & Cousin & Cousine & Success & QRep 3 \\
\hline 2002 & Cousine & Cousin & Success & SMART News 2, 2002 \\
\hline 2002 & Cousin & Praslin & $\begin{array}{l}\text { Return to Cousin by itself, } \\
\text { eventually accepted. }\end{array}$ & SMART News 2, 2002 \\
\hline 2003 & Cousine & Cousin & Success & Smart news 5, 2003 \\
\hline 2003 & Cousine & Praslin & $\begin{array}{l}\text { Unknown } \\
\text { Return to Cousin by itself, }\end{array}$ & Smart news 5, 2003 \\
\hline 2003 & Cousin & Praslin & eventually accepted. & Smart news 5, 2003 \\
\hline 2004 (Aug 26 $\left.6^{\text {th }}\right)$ & Aride & Denis & Disappeared on Denis & SMART News 6, 2004 \\
\hline 2005 & Cousin & Cousine & Success & SMART News 8, 2005 \\
\hline 2006 & Cousin & Cousine & $\begin{array}{l}\text { Unknown } \\
\text { Caught on Curieuse and }\end{array}$ & SMART News 10, 2006 \\
\hline 2007 & Aride & Curieuse & transferred to Cousin. & SMART News 12. 2007 \\
\hline 2008 & Cousin & Aride & Success & SMART News 13. 2008 \\
\hline $2010\left(11^{\text {th }} \mathrm{Oct}\right)$ & Cousine & Cousin & Success & SMART News 17,2010 \\
\hline
\end{tabular}




\section{Threats}

Causes of death of Magpie-robins have been recorded whenever circumstances allow over the past 20 years. Whenever corpses are found an examination is carried out to record any obvious cause of death. The thoroughness of necropsy has varied over time with the availability of trained personnel. The majority of birds that disappear are not found and therefore there is a large proportion of mortality in Magpie-robin that is unaccounted for. Of the deaths accounted for, the majority of accidental deaths occurred on the resort islands where infrastructure, development and human habitation is highest. The highest cause of non-accidental deaths based on observations and examinations is interspecific conflict. The two most significant threats to Magpie-robin population at present are invasive alien predators and disease. In particular, Barn Owls and Common Mynas pose a serious threat to Magpie-robin populations, and continued vigilance on all islands is necessary to reduce the impacts of these alien predators. The recent (2013-2014) reports of disease on Aride and Frégate have sparked concerns that Magpie-robins are vulnerable to a potentially devastating disease or infection and steps have been taken by SMART to investigate this. A recent visit by Wildlife Vets International (WVI) has discovered a parasite (Atoxoplasma) in the Magpie-robins of Aride and one bird on Cousin. Atoxoplamsa is a parasite that is found primarily in passerines. Clinical signs are non-specific and the disease causes rapid and fatal decline particularly in fledglings where a mortality rate of $80 \%$ can be seen. It is not known if this is the sole cause of decline but it has been known to cause death and rapid decline in groups of passerines (Sakas 2002).

\section{Frégate:}

The bacterium Erisipelothrix rhusiopathae was once identified from a dead Magpie-robin on Frégate but this is thought to be commonly occurring and is very widespread. The bacterium is common in soil, fish and particularly pigs and veterinary advice suggests it is likely to be present on most if not all islands (Thompson 2002). Overall this is thought not to have a significant impact on a healthy bird population. One incident of a mystery eye infection resulting in mortality has so far been reported on Frégate in early 2014. Other deaths caused by hotel infrastructure such as road collisions and accidental drowning in swimming pools and accidental trapping within villas have been reported (T. Liebrick pers. comm. 2014). Several incidences of Magpie-robins found dead in nest boxes have also been reported. The eradications of cats and rats, and recently the eradication of the Common Myna (Canning 2011), have had a positive effect on Magpie-robin population size. Mynas compete for nesting sites including nest boxes and cases of Magpie-robins killed by Common Mynas have been reported by island staff on Frégate (Rocamora and Henriette in press). Though re-invasion has occurred on occasions, the island staff rapidly locate and trap birds to reduce their chances of breeding. These incidents do not seem to impact the population, though Frégate conservation staff do their upmost to reduce non-natural Magpie-robin mortality.

\section{Aride:}

This population is in decline and at present the cause is unknown although several observations have been made. Several birds, particularly fledglings have been reported to have a fatal disease with symptoms manifested in an eye infection, weakness and diarrhoea. Staff have reported that fledglings tend to disappear within weeks of fledging and in some instances aggression by parents is the cause. In 2014 there was a complete lack of recruitment to the population that further hindered population stability. A thorough assessment is vital to prevent further declines. Previous reports of disease on Aride have been made. In 1996 Erisipelothrix rhusiopathae was identified in two recovered bodies (Parr 1998). Barn Owls have been recorded on Aride and a breeding population of c.20 birds was eradicated in 1996 (Betts 1997, Rocamora and Henriette in press). Once sighted, Barn Owls are dispatched immediately by island staff; however, although the species no 
longer breeds on Aride the constant incursion of birds from Praslin represents a potential threat to the Magpie-robins. Other causes of death such as entanglement with Pisonia grandis seeds and accidental death by drowning have been recorded. Ticks have been reported as an issue affecting birds on Aride although no deaths reported so far.

\section{Cousin:}

There have been no reported incidences of disease or infection in the Cousin birds, though it is rare to find the carcasses of dead birds, so determining cause of death is infrequent. Those carcasses that have been found usually show evidence of fighting such as pulled feathers or injuries around the eyes. A dead subadult was found in February 2015 decapitated, which indicates that it was killed by a Barn Owl; the second recorded Magpie-robin kill by a Barn Owl on Cousin. Other causes of death on Cousin have included several birds being found dead in nest boxes during breeding attempts, cause unknown, also birds becoming entangled in the seeds of Pisonia grandis the most abundant native tree on Cousin. A dead Magpie-robin was found in Feb 2015 with post-mortem results showing cause by bacterial sepsis.

\section{Cousine:}

The presence of Oxyspirura sp. (eye worms) was recorded in Cousine Magpie-robins in 2007. These nematodes are more commonly recorded in poultry and it is suspected that they were introduced to the island when chickens were present prior to 1990. The nematodes rely on an intermediate host (cockroaches) where the eggs are ingested from the droppings of birds. The robins then prey upon the cockroaches where the final stage of the eye-worms is completed. Young birds seem to be most susceptible, possibly due to a lack of resistance to the nematodes. Adults seldom show symptoms unless they are ill. No mortality was recorded. A bacterial septicaemia was also recorded after three birds became fatally ill within the same period, but the source was unconfirmed and no cases have been recorded since. Other incidents have included accidental drowning of one bird and accidental death of a bird that flew into a ceiling fan. Cousine has also had incidents where birds were found dead in the nest box during incubation. No reports of Magpie-robin deaths from Barn Owls have yet been recorded although Barn Owls have been sighted over the years. Barn Owls are dispatched as speedily as possible. Invasive alien predators and introduced disease are the largest potential threats to the Cousine birds at present.

\section{Denis:}

The main threat to the Denis Island Magpie-robin population has been the presence of Common Myna, known to predate nests and compete for nest sites with native birds (Millett et al. 2004, Rocamora and Henriette in press), particularly the Magpie-robin. An eradication programme was successful in 2015, removing this threat though vigilance against recolonisation will be a priority. Two previous reports of unknown disease/infection have been recorded, though not in enough detail to diagnose with confidence. So far no samples have been taken.

\section{The future}

\section{Frégate}

The owner of Frégate Island remains dedicated to the conservation of the Magpie-robin and as such will continue to employ resident conservation staff who will be trained in Magpie-robin monitoring, ringing and blood sampling in collaboration with SMART. The population on Frégate will be continually monitored with annual or bi-annual surveys carried out, and ringing of individuals throughout the year. Ongoing habitat restoration is planned and upcoming surveys will 
aim to assess the current carrying capacity of the island in relation to this. Keeping the island free of rats and Common Mynas remains a top priority which will hopefully ensure the continued success of the Magpie-robin population on Frégate Island.

\section{Aride}

The population will continue to be monitored closely and the supplementary feeding stopped as soon as the population reaches stability at a minimum of 30 birds as suggested by the ICS scientific committee. An endowment fund has been established by ICS UK, generating income that is remitted to ICS to support conservation activities on Aride. Further habitat management on the hill will be implemented in an attempt to attract Magpie-robin into new areas. More studies will be required to determine the causes of the current population decline and collaboration between SMART and WVI will be essential for this. As a Special Reserve, Aride has full protection and ICS Seychelles has the responsibility to care for and to keep the Magpie-robin population monitored at all times.

\section{Cousin}

The future of Magpie-robin on Cousin is safeguarded; the island is owned by Birdlife International and managed by Nature Seychelles, identified as an Important Bird Area (IBA; Rocamora and Skerrett 2001) and classified as a Special Reserve. The revenue from educational tours during the week provides enough income to support a full time conservation officer, enabling continuation of the close monitoring and management of Magpie-robins on Cousin.

\section{Cousine}

Due to the owner's dedication to conservation and to the island's obligation to the SMART programme objectives, the population of Magpie-robin on Cousine has been monitored over the long-term and protected accordingly. A conservation manager is permanently employed and is responsible for the logistics of managing the Magpie-robin population and for the communication and collaboration with other SMART stakeholders. Equipment and funds for managing the population will be available for the foreseeable future and the project will continually be a primary priority on the island. A Cousine trust will be set up to ensure the continued preservation of the island should it pass to new owners.

\section{Denis}

Annual population surveys will be continued. In collaboration with SMART, Denis Island staff have received training (May 2014) in Magpie-robin monitoring, ringing and blood sampling and as of 2015 all birds are currently ringed and have had blood samples taken. Continued efforts towards maintaining Denis Island as invasive alien predator free and continued habitat rehabilitation will hopefully result in continued increase of Magpie-robin numbers until population carrying capacity is reached. In collaboration with Green Islands Foundation, Denis Island management is committed to maintain a thriving and well-monitored population of Magpie-robins for the foreseeable future.

\section{Discussion}

Magpie-robin numbers have risen steadily due to a combination of management strategies: eradication of invasive alien species (IAS), translocations of breeding birds to four islands, and habitat restoration to increase the suitable foraging area. As for other rare and threatened species, the translocation of birds to other predator-free islands and subsequent breeding success has increased 
population numbers and reduced the risk of extinction (Rocamora and Henriette in press). The success of translocations is dependent on several factors such as the methods used and ongoing, long-term management of the population. The management of Magpie-robins can so far (since the 1994 translocation to Cousin) be considered a success due to the population increase and subsequent downgrading from 'Critically Endangered' to 'Endangered' on the IUCN Red List. The recent decline in population size on Aride Island has highlighted the fragility of these small populations. A combination of decline in adult birds coupled with lack of recruitment means the Aride population is now in danger of becoming extinct.

The incidences of Magpie-robin mortality reported in 2013/2014 highlighted the lack of expertise and facilities to deal with unknown diseases in the Seychelles, particularly those affecting endemic birds. A sampling protocol is now in place with equipment provided by the International Zoological Veterinary Group (IZVG) and Wildlife Vets International (WVI). Samples have been collected by WVI and analysed by IZVG pathologists in the UK, who concluded that the Aride birds were infected with a parasite that could be responsible for deaths especially in juvenile birds. It is too early to say if this is the contributing factor or whether other factors also come into play. One important factor to consider when analysing the success of translocations is the preservation of genetic diversity. A recent study by Wright et al. (2014) on the genetic impacts of translocating the Seychelles Warbler found that nearly all the genetic variation observed in the original population on Cousin was captured in the translocated birds, reducing the severity of any additional inbreeding depression that may occur due to the translocation of small numbers of founders. Further to this, each new population received all of the known immunity gene variation investigated in the study (MHC class I genes), meaning that all five populations appear equally prepared for immunological challenges they may encounter. López-Sepulcre et al. (2008) expressed concern that the dip in the Magpie-robin population on Cousin Island may be the result of cumulative inbreeding effects due to the limited genetic diversity from such a small founder population. A rise in population size and subsequent stability of the population have alleviated these concerns. However, since no population genetics work has been carried out on Magpie-robins, it is unclear whether inbreeding may have played a limiting factor in the growth of Magpie-robin populations. It does however throw light on the subject of future translocations for this and other species that have undergone a severe bottleneck and where genetic diversity in the founder population is already impoverished. If translocated populations lack any of the immunity gene variation then a lack of natural defence may hinder conservation efforts. This is a possible yet unproven cause of the Aride population decline.

Inbreeding contributes to the vulnerability to extinction of island populations, but exchange of immigrants among isolated populations should reduce extinction rates (Frankham 1996). The inter-island movements of Magpie-robins over the past 20 years have mainly occurred between Cousin and Cousine $(50 \%)$ with just one bird migrating to Aride Island $(7 \%)$ and six birds migrating to islands with no Magpie-robins present (42\%). Although the number of successful migrations is low, the genetic benefits to the isolated populations may be great and in this case those benefits would have mostly been seen on Cousin and Cousine. In general a minimum of one migrant per generation is sufficient to minimise the loss of polymorphism and heterozygosity within subpopulations while allowing for divergence in allele frequencies among subpopulations (Mills and Allendorf 1996). With the average lifespan of Magpie-robin being 2.6 years old, and longest lived 15 years old (Gane and Burt 2016), it is likely that the Cousin/Cousine Magpie-robins could be considered one population, based on inter-island movements, whereas Frégate, Aride and Denis are isolated populations. Further studies are required to investigate this. Blood samples have been collected from each bird since translocations began on four out of the five Magpierobin islands so genetic analysis is a possibility should funding and institutional support become available.

The successful conservation of Seychelles Magpie-robins with increased population density has brought new limiting factors to population recovery. When breeding cooperatively, subordinates increase the frequency of territorial take-over of established breeders, which effectively 
slows recovery (López-Sepulcre et al. 2009). Indeed both Cousine and Cousin both show a significant relationship between population growth and a decrease in adult annual survival (Gane and Burt 2016) a likely result of increased territorial conflicts. Further studies showed that these disputes can be alleviated by reducing variation in habitat quality via active conservation management (López-Sepulcre et al. 2010). Whether this is impacting the Aride population is unclear, though reports of juveniles being chased away by parents soon after independence is reached (and subsequent disappearance of juveniles) is indicative of the negative impacts of territorial conflicts on population growth.

The Magpie-robin was the focus of intense management, funding and research throughout the 1990 but since 2002 each island has been responsible for monitoring and managing its Magpie-robin population. After the point when conservation success had been achieved by increasing the population and particularly from 2008 onwards, there has been little interest in the continuing story of this bird. The consequence is that there is no real understanding of the drivers behind population growth or decline and island managers and conservation staff are aware that it would only take something small to reverse population increases and all the efforts made to conserve this species. Further research focused on the cause of death and reproductive fitness is essential to better understand the factors affecting the translocation success of island endemic birds.

Further population increase is possible for the Magpie-robin populations on Frégate and Denis Islands, following continued habitat restoration and continued vigilance against invasive alien species. Overall population numbers may fluctuate depending on whether current threats are alleviated. Further translocations are the most appealing method of increasing the population and reducing the risk of extinction. However suitable islands would need to be predator-free (or nearly predator-free) with a large area of suitable habitat and food (i.e. good levels of ground dwelling insects/invertebrates and fresh water sources) and the support of island owners and managers for monitoring and protection of the species once translocated. North Island is one prospective island and interest from the owners has been expressed, however funds are required to carry out pretranslocation surveys and an agreement signed between all concerned parties to set out conditions of translocation and bird management.

When considering the future of the individual Magpie-robin populations each island was able to guarantee continued monitoring and protection under the current management. However for the three privately owned islands there is no guarantee that if the islands change hands in future that protection of endemic birds will be a stipulation of sale. There is no current legislation to protect the habitat of endemic birds on privately owned islands. The current owner of Cousine Island has alleviated this problem by setting up a trust, with trustees being responsible for ensuring that conservation and protection of Cousine and its flora and fauna continues into the future. This would be a highly desirable solution for both Denis and Frégate islands. It would be a great shame if at this stage in the story of the charismatic Seychelles Magpie-robin there were a decline due to disease or neglect of management. All parties concerned are responsible for the continued success of this species and must work together to maximise management effectiveness and research efforts.

\section{Acknowledgements}

The authors would like to acknowledge the many persons involved in the Seychelles Magpierobin recovery programme over the years. In particular we would like to acknowledge Nature Seychelles for facilitating SMART continuation in the absence of funds. Thanks to all the island management and owners for supporting this project. Thanks to Dr Gerard Rocomora, Adrian Skerrett, Dr Dave Wright and an anonymous referee for their insights and recommendations on the manuscript. Finally we would like to acknowledge the help of Wildlife Vets International, in particular Andrew Greenwood and Johanna Storm, for providing support and expertise to the Magpie-robin Islands in response to the Aride population decline. 


\section{References}

Baker, B. H. (1963) Geology and mineral resources of the Seychelles Archipelago. Geol. Surv. Kenya Memoir 3: 1-29.

Betts, M. (1997) Aride Island Nature Reserve, Seychelles. Annual Report 1996. Lincoln, UK: Royal Society for Nature Conservation. (Unpublished report).

Blackburn, C. A. (1878) Quelques courtes descriptions des oiseaux de Praslin. Trans. Roy. Soc. Arts Sci. Maurice 12: 125-13.

Bristol, R., Millett, J. E. and Shah, N. J. (2005) Best practice handbook for management of a critically endangered species: the Seychelles Magpie-robin. Mahé, Seychelles: Nature Seychelles. (Unpublished report).

Canning, G. (2011) Eradication of the invasive common myna, Acridotheres tristis, from Frégate Island, Seychelles. Phelsuma 19: 43-53.

Crook, J. (1960) The present status of certain rare land-birds of the Seychelles Islands. Seychelles Government Bulletin. (Un-numbered)

Dawson, P. G. (1965) Bristol University Seychelles Expedition, part 6: Frigate, home of the Magpie Robin. Animals 7: 520-522.

Feare, C. J. (2010) [Online]. Eradication of Common Mynas from Denis Island, Seychelles. Available from: http://denisisland. blogspot.com

Frankham, R. (1996) Relationship of genetic variation to population size in wildlife. Conservation Biology 10: 1500-1508.

Gane, J. and Burt, A. J. (2016) Longevity and survival of the Endangered Seychelles Magpie-robin Copsychus sechellarum. Ostrich 87: 81-83.

Gaymer, R., Blackman, R. A. A., Dawson, P. G., Penny, M. and Penny, C. M. (1969). The endemic birds of the Seychelles. Ibis III: $157-176$.

Gerlach, J. and Le Maitre, S. (2009) Sex ratio variation in small island populations of an endangered bird, the Seychelles Magpie Robin, Copsychus sechellarum. Ostrich 72: 114-117.

Hartlaub, G. (1877). Die Vögel Madagascars und der benachbarten Inselgruppen: ein Beitrag zur Zoologie der äthiopischen Region. Halle, Germany: HW Schmidt.
Hill, M. J. (2001) Habitat rehabilitation on Denis Island 2001-2. Final Report. Mahé, Seychelles: Nature Seychelles. (Unpublished report).

Hill, M. J., Vel, T. M., Holm, K. J., Parr, S. J. and Shah, N. J. (2002) Biodiversity surveys and conservation potential of inner Seychelles islands. Atoll Res. Bull. 495: 48-70.

Johnson, T. H. and Stattersfield, A. J. (1990) A global review of island endemic birds. Ibis 132: $167-180$.

Komdeur, J. (1996) Breeding of the Seychelles Magpie Robin Copsychus sechellarum and implications for its conservation. Ibis 138 : 485-498.

Le Maitre, S. (1994) The Seychelles magpie robin recovery plan: Cousin translocation. Progress Report 1. Cambridge, UK: BirdLife International, unpublished report.

Le Maitre, S. (1995a) The Seychelles magpie robin recovery plan: Cousin translocation. Progress Report 2. Cambridge, UK: BirdLife International. Unpublished report.

Le Maitre, S. (1995b) The Seychelles Magpie Robin Recovery Plan. Cousin translocation. Progress report 3. Internal report. Cambridge, UK: BirdLife International.

Le Maitre, S. (1996a) The Seychelles Magpie Robin Recovery Plan. Aride, Cousin and Cousine translocations: Progress report 5. Mahé, Seychelles: BirdLife International. (Internal report).

Le Maitre, S. (1996b) The Seychelles Magpie Robin Recovery Plan. Aride and Cousin translocations: Progress report 6. Mahé, Seychelles: BirdLife International. (Internal report).

Lionnet, J. F. G. (1980). Les oiseaux observés aux Seychelles en 1768 au cours del'expedition Marion Dufresne. Proc. Pan-Afr. Ornithol. Congr. 4: 65-69.

López-Sepulcre, A., Doak, N., Norris, K. and Shah, N. J. (2008) Population trends of Seychelles Magpie-robins Copsychus sechellarum following translocation to Cousin Island, Seychelles. Conserv. Evidence 5: 33-37.

López-Sepulcre, A., Norris, K. and Kokko, H. (2009) Reproductive conflict delays the recovery of an endangered social species. J. Anim. Ecol. 78: 219-225. 
López-Sepulcre, A., Kokko, H. and Norris, K. (2010) Evolutionary conservation advice for despotic populations: habitat heterogeneity favors conflict and reduces productivity in Seychelles magpie robins. Proc. Roy. Soc. B. 277: 3477-3482.

Lucking, R. S. and Ayrton, V. (1994) The Seychelles Magpie Robin Recovery Plan. Aride Translocation: Progress report 11. Mahé, Seychelles: BirdLife International. (Internal report).

Lucking, R. S. and Ayrton, V. (1995) The Seychelles Magpie Robin Recovery Plan. Aride Translocation: Summary Report, November 1992-November 1994. Mahé, Seychelles: BirdLife International. (Internal report).

Lucking, R. and Lucking, V. (1997) The Seychelles Magpie Robin Copsychus sechellarum Pp. 119-130 in G. Rocamora, ed. Rare and threatened species, sites and habitats monitoring programme in Seychelles. Project G1 EMPS. Volume 1. Monitoring methodologies and recommended priority actions. Victoria, Seychelles: Ministry of Environment/BirdLife International/EU.

McCulloch, N. (1996) The Seychelles Magpie Robin: first steps on the road to recovery. Bull. Afr. Bird Club 3: 81-84.

Mee, A. (1996) Seychelles Magpie Robin recovery programme: Cousin translocation. Mahé, Seychelles: BirdLife International. (Unpublished report).

Merton, D. (2001) Report on eradication of rats from Curieuse, Denis and Frégate Islands and cats from Curieuse and Denis Islands, May-August 200o. Mahé, Seychelles: Report to Director of Conservation, Ministry of Environment \& Transport.

Merton, D., Climo, G., Laboudallon, V. and Robert, S. (2001) Alien animal eradication and quarantine on islands in the Seychelles. Turning the tide: the eradication of invasive species. Auckland, New Zealand: Invasive Species Specialist Group, IUCN.

Millett, J. and Shah, N. J. (2000) Seychelles Magpie- robin Recovery Program. Review of Progress 2000. Mahé, Seychelles: BirdLife Seychelles.

Millett, J., Climo, G. and Shah, N. J. (2004) Eradication of common Myna Acridotheres tristis populations in the granitic Seychelles: successes, failures and lessons learned. Advances in Vertebrate Pest Management 3: $169-183$.

Mills, L. S. and Allendorf, F. W. (1996) The one-migrant-per-generation rule in conservation and management. Conserv. Biol. 10: 1509-1518.

Newton, E. (1867) On the landbirds of the Seychelles Archipelago. Ibis 3: 335-36o.

Norris, K. and McCulloch, N. (2003) Demographic models and the management of endangered species: a case study of the critically endangered Seychelles Magpierobin. J. Appl. Ecol. 40: 890-899.

Oustalet, M. E. (1878) Etude sur la faune ornithologique des iles Seychelles. Bull. Soc. Philomath. Paris 2: 161-206.

Parr, S. (1998) The history of Seychelles Magpie Robin translocations as a guide to future actions: a position paper. Mahé, Seychelles: BirdLife Seychelles. (Unpublished report).

Parr, S. J. and Shah, N. J. (1999) Seychelles Magpie Robin Recovery Programme: Review of Progress 200o. Mahé, Seychelles: BirdLife Seychelles. (Unpublished report).

Pike, N. (1872) A visit to the Seychelles islands. Trans. R. Soc. Arts Sci. Maurit. ser. B 6:83-142.

Ridgeway, R. (1895). On birds collected by Dr. W.L. Abbott in the Seychelles, Amirantes, Gloriosa, Assumption, Aldabra, and adjacent islands, with notes on habits etc., by the collector. Proc. U.S. Nat. Mus. 18: 509-546.

Rocamora, G. and Henriette, E. (2015) Invasive alien species in Seychelles. Why and how to eliminate them. A manual for identification and management of priority species. Collection Inventaires et Biodiversité. Museum National d'Histoire Naturelle, University of Seychelles. Biotope Editions.

Rocamora, G. and Skerrett, A. (2001). Seychelles. Pp. 751-768 in L. Fishpool and M. I. Evans, eds. IBAs in Africa and associated islands. Cambridge, UK: Pisces Publications / BirdLife International.

Sakas, P. S. (2002). Adapted from essentials of avian medicine: A guide for practitioners. Second Edition. Lakewood, Colorado: American Animal Hospital Association Press.

Samways, M. J., Hitchins, P. M., Bourquin, O., and Henwood, J. (2010). Restoration of a tropical island: Cousine Island, Seychelles. Biodiv. Conserv. 19: 425-434. 
Shah, N. J. and Parr, S. J. (1999) Inter-island movements by Seychelles Magpie-robins Copsychus sechellarum: attempts at re- colonisation? Bird Conserv. Internatn. 9: 283-284.

Shah, N. J. and Parr, S. J. (2002) Translocation of Seychelles magpie robins to Aride 2002-Progress of the translocated population January 2002 - October 2002. Mahé, Seychelles: BirdLife Seychelles. (Unpublished report).

Skerrett, A. and Disley, T. (2013) Birds of Seychelles. London, UK: A\&C Black.

Skerrett, A., Bullock, I. and Disley, A. (2001) Birds of Seychelles. London, UK: Helm Books.

Stoddart, D. R. and Fosberg, F. R. (1981) Bird and Denis Islands, Seychelles. Atoll Res. Bull. 252: 1-50.

Szabo, J. K., Khwaja, N., Garnett, S. T. and Butchart, S. H. M (2012) Global patterns and drivers of avian extinctions at the species and subspecies level. PLoS ONE 7(10): e47080. doi:10.1371/journal.pone.0047080

Thompson, J. (2002) The translocation/ reintroduction of two species of Seychelles Island endemic birds to Aride Island Nature Reserve during the North West monsoon.
January -February 2002. Mahé, Seychelles: Unpublished report to ICS.

Thorsen, M., Shorten, R., Lucking, R. and Lucking, V. (2000) Norway rats (Rattus norvegicus) on Frégate Island, Seychelles: the invasion; subsequent eradication attempts and implications for the island's fauna. Biol. Conserv. 96: 133-138.

Vesey-Fitzgerald, D. (1940) The birds of the Seychelles 1: The endemic birds. Ibis 14: $480-489$.

Watson, J. (1978) The Seychelles Magpie Robin. WWF Project 1590: Endangered land birds, Seychelles (Final Report I(a)). Gland, Switzerland: World Wildlife Fund. (Mimeo).

Watson, J., Warman, C., Todd, D. and Laboudallon, V. (1992) The Magpie-robin Copsychus sechellarum: ecology and conservation of an endangered species. Biol. Conserv. 61: 93-106.

Wright, D. J., Spurgin, L. G., Collar, N. J., Komdeur, J., Burke, T. and Richardson, D. S. (2014) The impact of translocations on neutral and functional genetic diversity within and among populations of the Seychelles Warbler. Molec. Ecol. 23: 2165-2177.

APRIL J. BURT ${ }^{1, *}$ NIRMAL SHAH

Nature Seychelles, PO Box 1310, Center for Environment and Education, Roche Caiman, Mahé, Seychelles.

${ }^{1}$ Seychelles Islands Foundation, La Ciotat Building, Mont Fleuri, P.O Box 853, Victoria, Mahé, Seychelles.

JULIE GANE, IAIN OLIVIER

Cousine Island, PO Box 977, Victoria, Mahé, Seychelles.

LICIA CALABRESE

Island Conservation Society, The Island Conservation Centre, P.O. Box 775, Pointe Larue, Mahé, Seychelles.

ARJAN DE GROENE

Green Islands Foundation, PO Box 246, ex-Vines Building, Victoria, Mahé, Seychelles.

TANYA LIEBRICK, DANE MARX

Frégate Island Private, P.O. Box 330, Mahé, Seychelles.

*Author for correspondence; e-mail: apriljaz@hotmail.com

Received 2 May 2015; revision accepted 14 December 2015; Published online 31 May 2016 